\title{
Investigation of Fire at Council, Alaska: A Release of Approximately 3000 Curies of Tritium
}

\author{
G. A. Jensen \\ J. B. Martin
}

\section{April 1988}

Prepared for the U.S. Department of Energy under Contract DE-AC06-76RLO 1830

Pacific Northwest Laboratory Operated for the U.S. Department of Energy by Battelle Memorial Institute 


\section{DISCLAIMER}

This report was prepared as an account of work sponsored by an agency of the United States Government. Neither the United States Government nor any agency thereof, nor Battelle Memorial Institute, nor any or their employees, makes any warranty, expressed or implied, or assumes any legal liability or responsibility for the accuracy, completeness, or usefulness of any information, apparatus, product, or process disclosed, or represents that its use would not infringe privately owned rights. Reference herein to any specific commercial product, process, or service by trade name, trademark, manufacturer, or otherwise does not necessarily constitute or imply its endorsement, recommendation, or favoring by the United States Government or any agency thereof, or Battelle Memorial Institute. The views and opinions of authors expressed herein do not necessarily state or reflect those of the United States Government or any agency thereof, or Battelie Memorial Institute.

\section{PACIFIC NORTHWEST LABORATORY operated by \\ BATTELLE MEMORIAL INSTITUTE for the \\ UNITED STATES DEPARTMENT OF ENERGY \\ under Contract DE-AC06-76RLO 1830}




IHUESTIGATION OF FIRE AT COUHCIL, ALASKA:

A RELEASE OF APPROXIMATELY 3000 CURIES OF TRITIUM

G. A. Jensen

J. B. Martin

April 1988

Prepared for

the U.S. Department of Energy

under Contract DE-AC05-76RLo 1830

Pacific Northwest Laboratory

Richland, Washington 99352 
' 


\section{SUMMARY}

On September 6, 1987, about 6:00 an, a fire was discovered in the comunity building at Council, Alaska, where 12 radioluminescent (RL) light panels containing approximately $3000 \mathrm{Ci}$ mere stored. All of the tritium in the panels was released as a result of the fire. This report sumarizes the recovery of the remains of the panels destroyed in the fire and investigations completed to evaluate the fire site for possible exposure of cormunity residents or contamination by tritiun release in the environment. Based on the analysis of urine samples obtained from individuals in the communty and from Pacific Northest Laboratory personnel participating in the recovery operation, no evidence of exposure to individuals was found. No tritiur (above normal background) was found in water and vegetation samples obtained at various locations near the site. 


\section{.}




\section{CONTENTS}

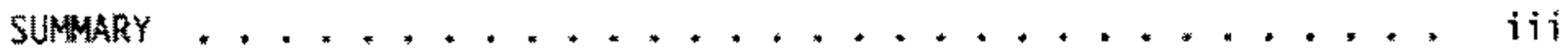

1.0 INTRONUCTION $\ldots \ldots \ldots$

2.0 BACKGROUND ...........,.......,........3

2.1 THE COUNCIL COMMUNTY AND FIRE SITE $\ldots \ldots . \ldots$

2.2 EVENTS SURROUNDING THE FIRE ...............4 4

2.3 COMMUNITY REACTION ........................ 8

2.4 NOTIFICATIONS ....................... 8

3.0 PlanNING, RECOVERY, SAMPLING AMD RESULtS $\ldots . \ldots \ldots$

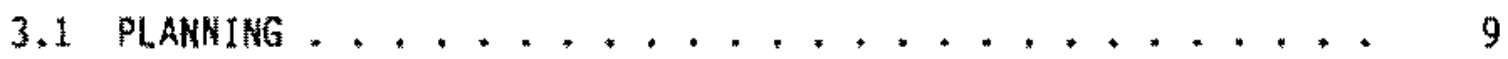

3.2 HANDLING ANO RECOVERY OF LIGHT TUBES . . . . . . . . 10

3.2 .1 Approach to the Fire Site .............. 10

3.2.2 Damaged RL Tube Recovery Procedure . . . . . . . . 12

3.3 SAMPLING, ANALYSIS, AND RESULTS ..............13

3.3.1 Badiation Survey Instruments . . . . . . . . . 13

3.3.2 Radiation Monitoring . . ............. 14

3.3 .3 Bioassay Samples .................... 19

3.3 .4 Environmental Samples.................. 21

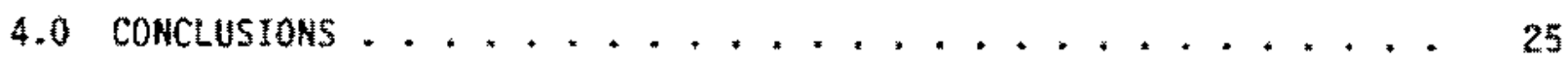




\section{FIGURES}

1. RL-Lighted Airfields in Alaska .............. 3

2. Melsing Creek Airport $\ldots \ldots \ldots$

3. Council, Alaska .................... 5

4. Fire Location, Council, Alaska ............. 5

5. Fire Site, Council, Alaska ..............

6. Fire Site, Council, Alaska ...............7

7. Fire-Danaged RL Light Panels .............. 10

8. Fire-Damaged RL Light Panels ................ 11

9. Fire-Damaged RL Light Panels ................ 11

10. Damaged RL Light Tubes in Polystyrene Packaging ........ 12

11. Damaged RL Light Tubes in Polystyrene Packaging . . . . . . 13

12. Vegetation Sanpling Locations Near Council ......... 22

\section{TABLES}

1. Tritium Smear Results ................. 16

2. Tritium Bioassay Results ................ 20

3. Environmental Sample Results ............... 23 


\subsection{INTRODUCTION}

On September 6, 1987, about 6:00 am, a fire was discovered in the community building at Council, Alaska, where 12 radioluminescent (RL) light panels were stored. The building was destroyed and all of the tritiun in the panels was released. Each panel had originally contained $350 \mathrm{Cj}$ of tritium (4200 $\mathrm{Cl}$ total), and approximately 3000 total $\mathrm{Ci}$ remained in all the panels after 4-5 years of use. The panels had been manufactured by 0ak Ridge National Laboratory (ORNL) for the U.S. Air Force by an interagency agreement with the Department of Energy (DOE) as a part of DOE's Radioluminescent (RL) Lights Program. A11 of the panels manufactured by ORNL are on loan to the State of Alaska, Department of Transportation \& Public Facilities (ADOTAPF) for demonstration, test, and evaluation for lighting remote rural airfields. The ADOT\&PF participates in DOE's RL. Lights Progran under the terms of Agreement DE-SCO1-84DP48024 with DOE Headquarters (DOE-HO) as amended.

The ADOT\&PF requested that Pacific Northwest Laboratory (PNL) ${ }^{(a)}$ investigate the aftemath of the fire and evaluate the situation to detemine whether residents of Council or the local environment received any tritium contamination and to recover any surviving lights or light residuals. A recovery plan was prepared (Appendix A), and the authors were assigned the tasks of recovering the damaged panels and of evaluating the site, surroundings, and the resident population for contamination.

This report is organized into sections covering introductory information, information on the site, community reaction, the recovery operation. and the analysis of biological and environmental samples collected at the site and at other locations. The methodology used to ship the remains of the panels is briefly described in Appendix $B$.

(a) Operated for the U.S. Department of Energy by Battelle Menorial Institute under Contract DE-ACO6-76RLO 1830. 


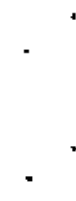




\subsection{BACKGROUND}

This section provides information on the site, a description of the event, community reaction to the fire, and incident reporting.

\subsection{THE COUNCIL COMMUNITY AND FIRE SITE}

Council, Alaska (Figure 1), is a community of about 12 permanent residents with additional part-time residents who own cabins in the community and commute from Nome. The community is located astride the Niukluk River approximately 50 air miles east of Nome, Alaska, and about 40 air miles north of the Norton Sound coastline at a latitude of $64^{\circ} 54^{\prime}$ and a longitude of $163^{\circ} 40^{\prime}$. A light-duty road connects the community with Nome from May until October, when snowfall makes it impassable; air transportation is available year round.

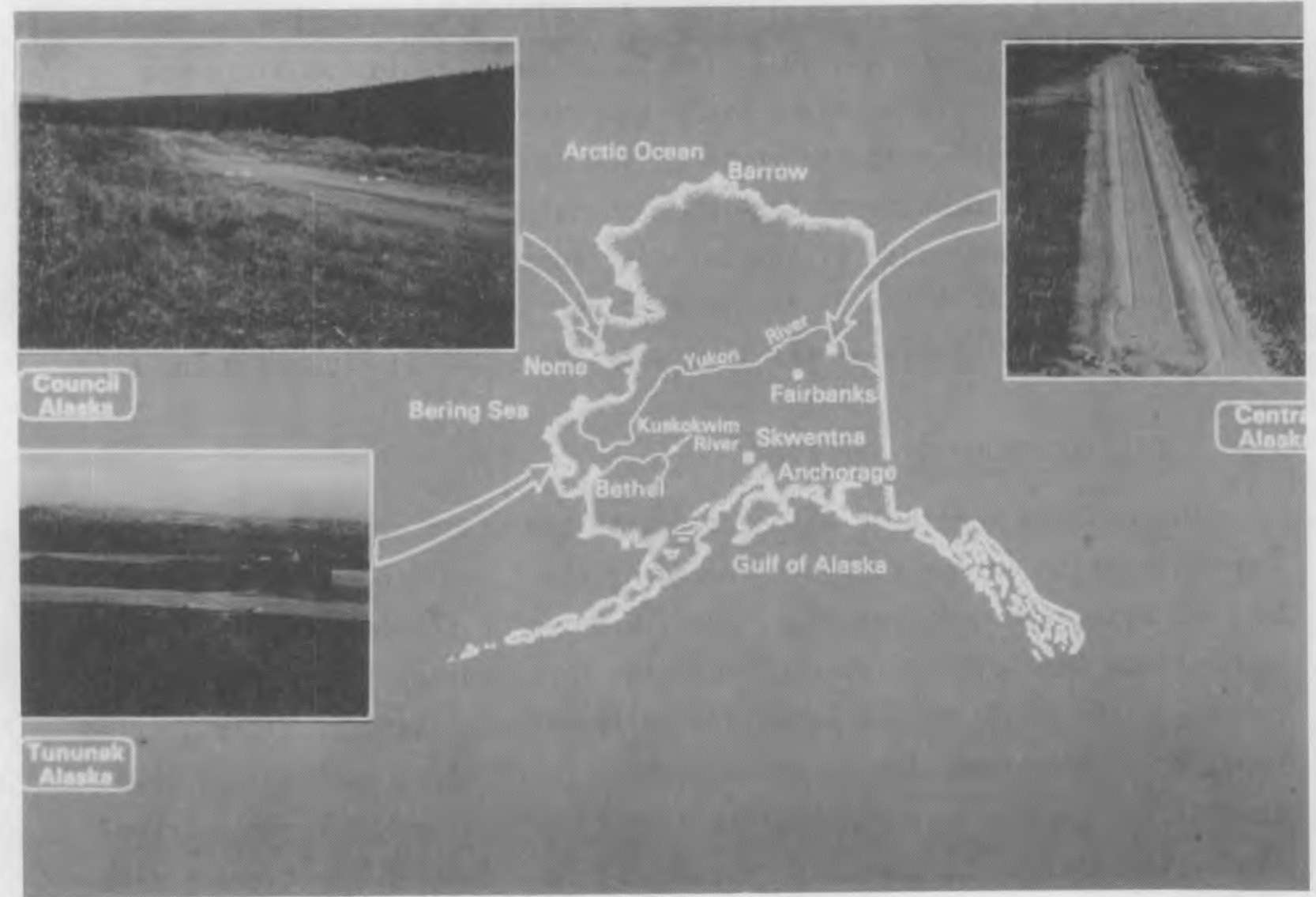

FIGURE 1. RL-Lighted Airfields in Alaska 
Radioluminescent (RL) lighting was installed on the community airfield (Melsing Creek Airport, Figure 2) in early October 1986. The original plans had called for RL threshold and edge lights, an RL lighted wind tee, and an RL-lighted visual approach slope indicator (VASI). Because the airfield is located in a hilly area, the VASI was not installed for safety reasons. The panels for the VASI were returned to Nome for storage. Although the wind tee was installed during the original airfield installation, the wind tee was not lighted at the time of installation and the RL panels were stored at Council. When the wind tee was lighted, the panels stored in Nome were used and those available in Council were held at Council as spares.

The conanunity building where the light panels were stored was a small rectangular house about $25 \mathrm{ft}$ by $35 \mathrm{ft}$ on a side, centrally located in the comanunity. Reportedly built in 1975 or 1976, it was used for storage and to house the community telephone, television electronics and other communications equipment. Books, two old power transformers, and other items along with the RL lights were stored in the building. An Alascom microwave receiver dish, fuel tanks and a small generator house are located within a $100-\mathrm{ft}$ radius to the west and north of the building location. Abandoned buildings and residences are located at greater distances beside the road to the east, west, and south of the building location (Figures 3 and 4). No structures other than the microwave receiver dish are located north of the building site. Pictures of the fire site are shown in Figures 5 and 6 .

\subsection{EVENTS SURROUNDING THE FIRE}

Discussions were held with residents, the state police, and others having information on the events surrounding the fire. The fire was discovered by Fred Muze, a nearby resident, about 6:00 am on September 6, 1987. He, Annie Stang, and others reported that the fire started in the northeast corner of the building and rapidly engulfed the building in flames. Fred reported that he immediately awakened members of the community and that several helped him move vehicles (a dump truck and tanker truck) parked nearby to safety. Fortunately, the nearby fuel tanks did not catch fire. 


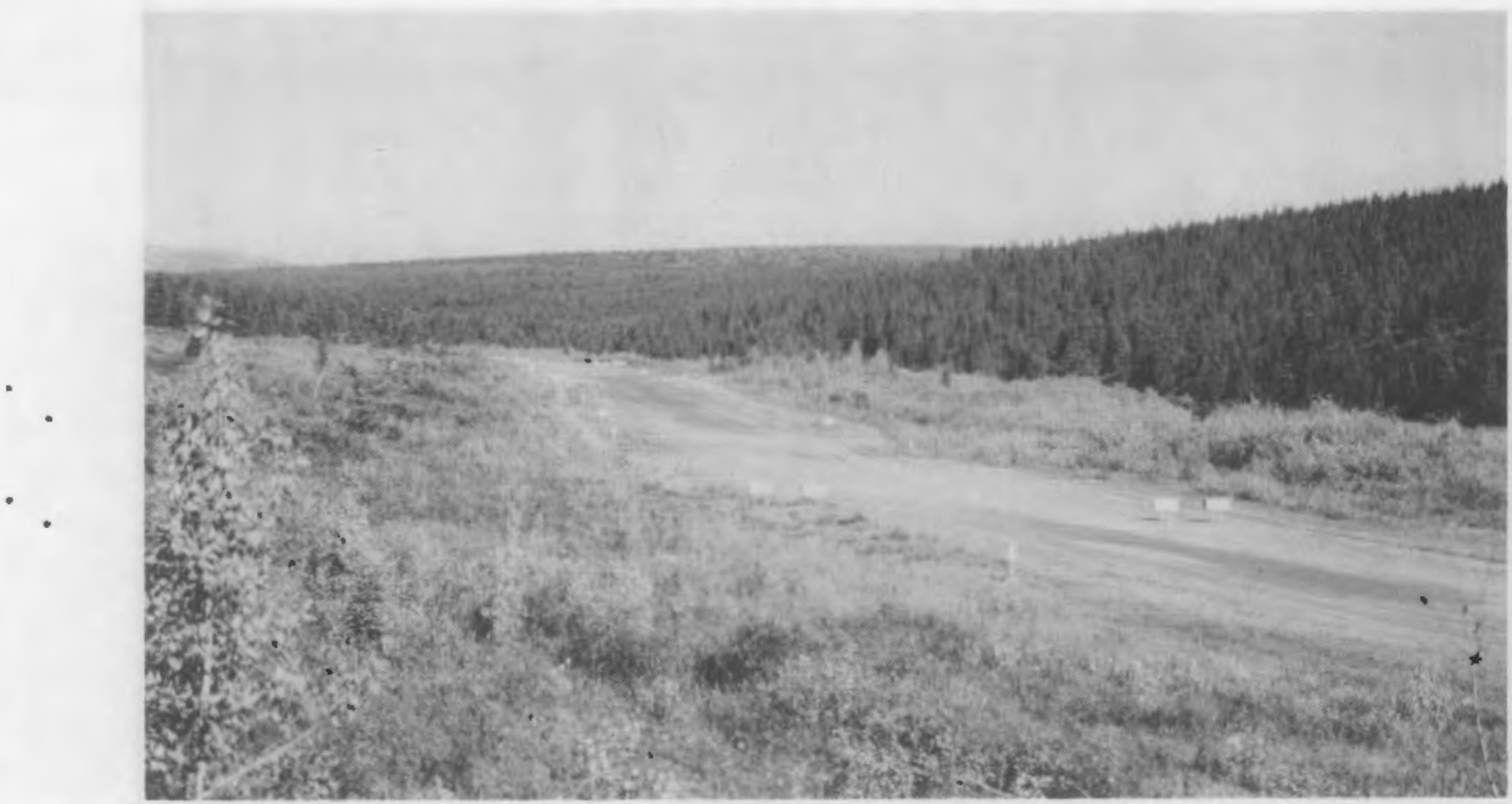

FIGURE 2. Melsing Creek Airport

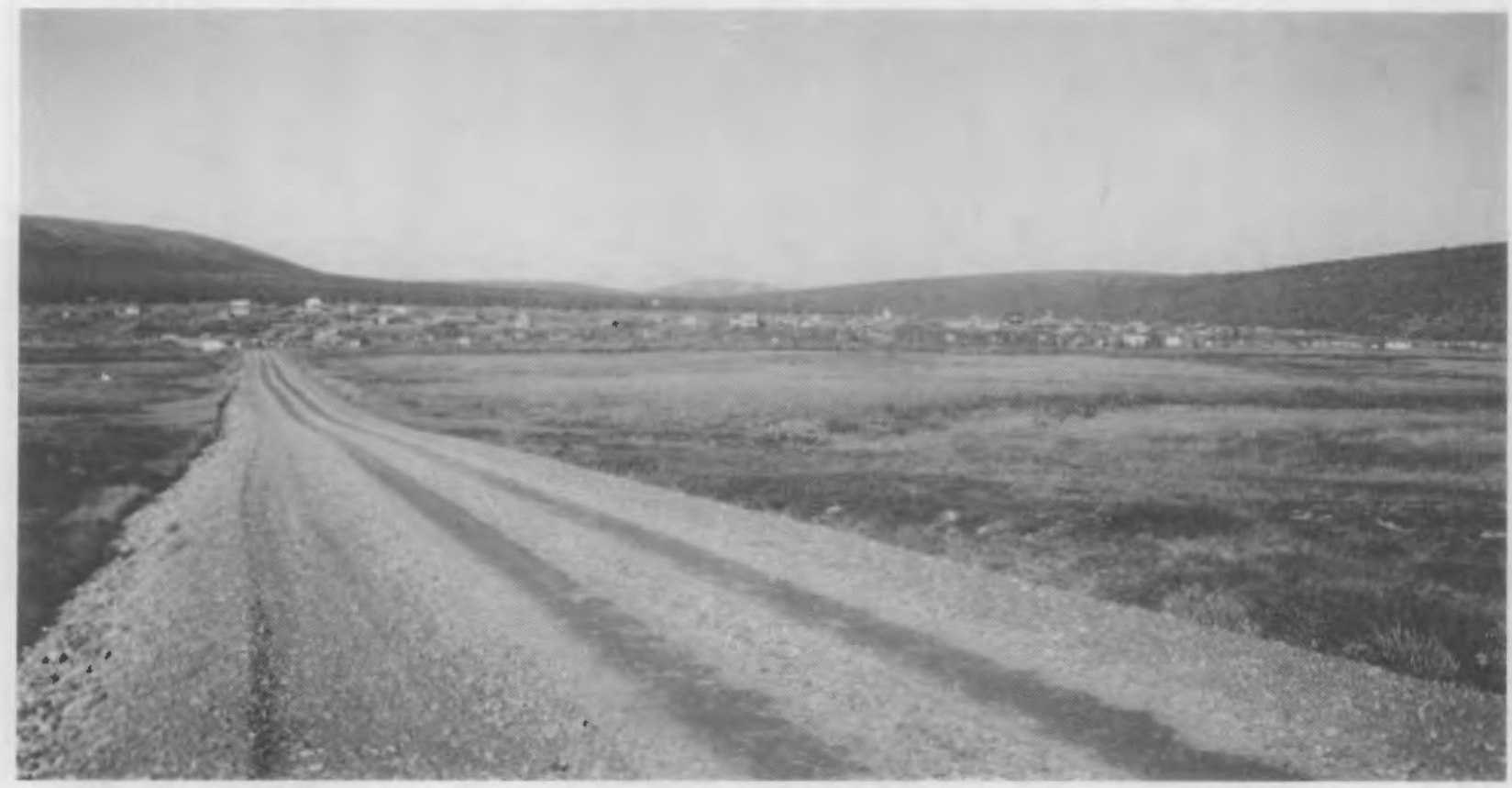

FIGURE 3. Council, Alaska 


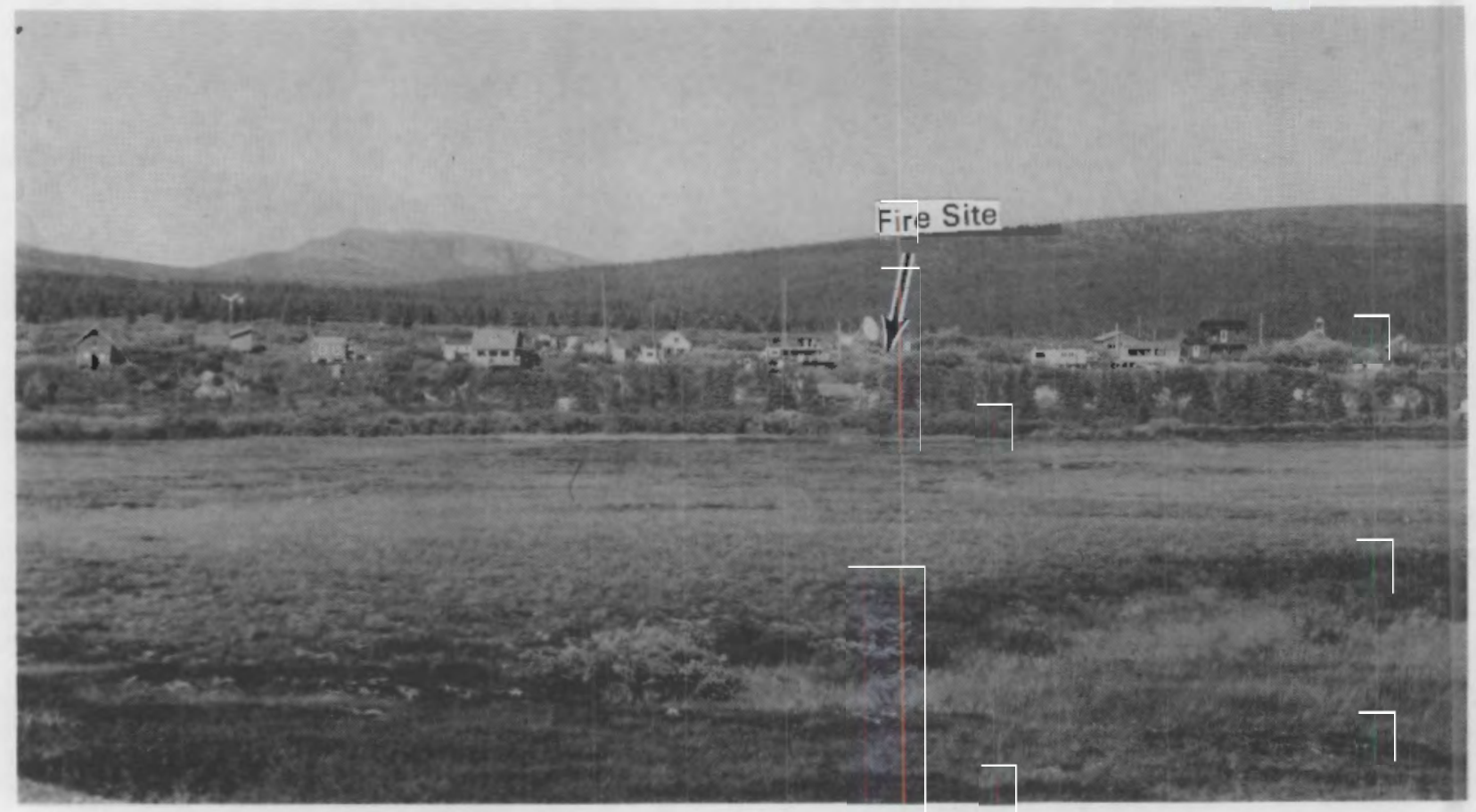

FIGURE 4. Fire Location, Council, Alaska

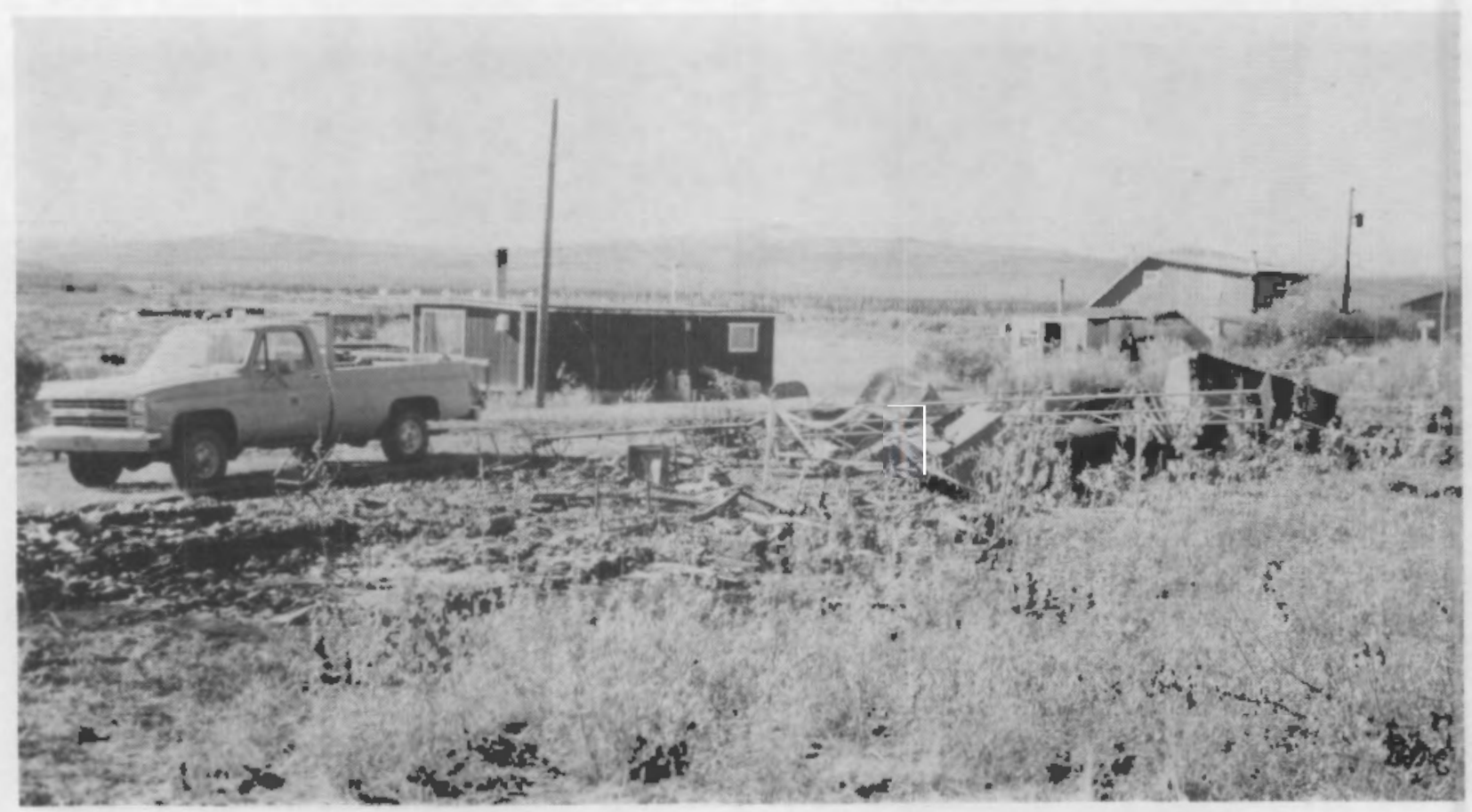

FIGURE 5. Fire Site, Council, Alaska 


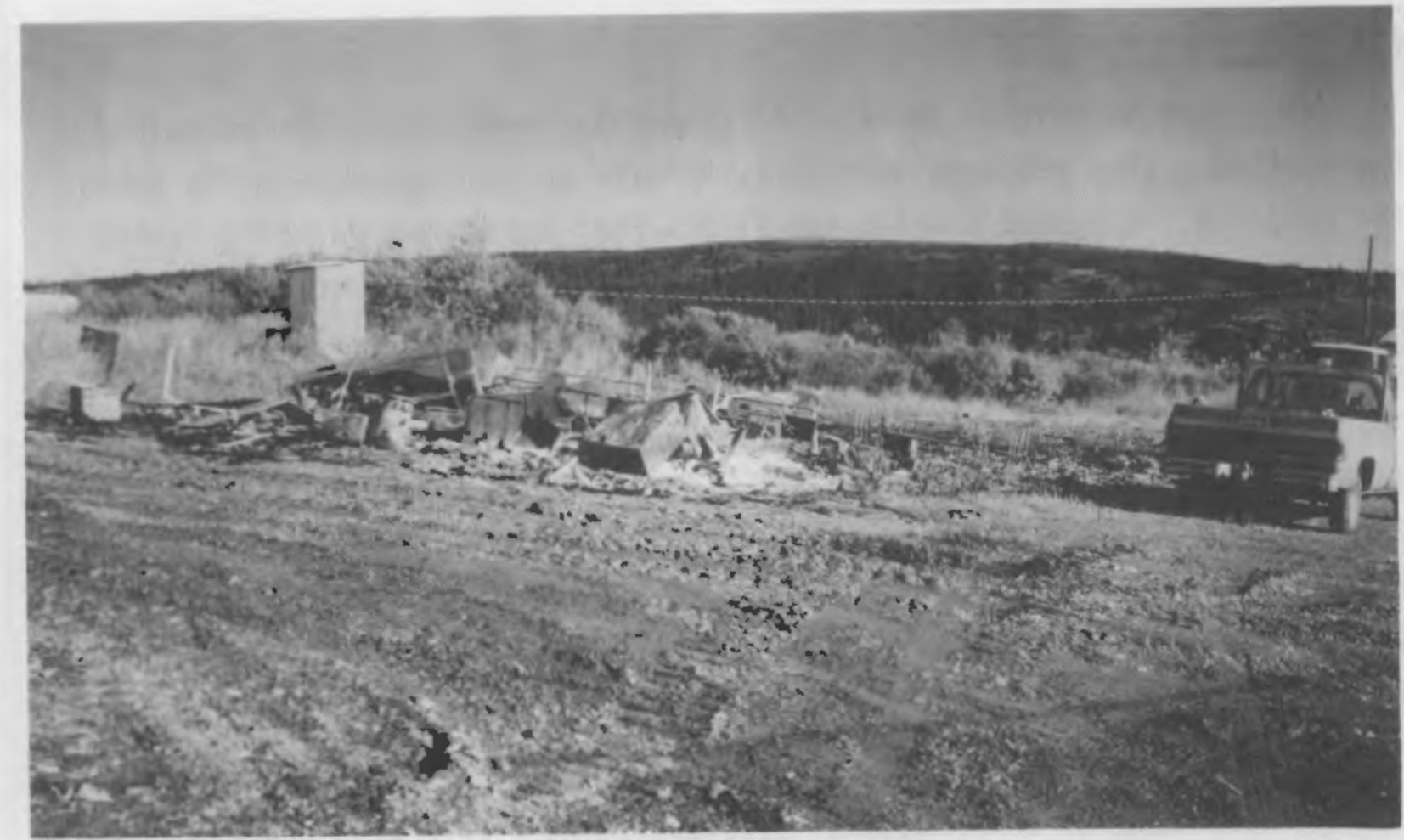

FIGURE 6. Fire Site, Council, Alaska

Those witnessing the fire reported that the fire burned very hot, flames reaching $30 \mathrm{ft}$ or more in height, that the plume went straight up since there was little or no wind, and the sky was thinly overcast. One witness, Harlen Holly, reported that there was a very light wind, more of a wind drift, to the northeast. A light rain started about 9:00 am. All witnesses reported that the building was engulfed in flames within 10 to $15 \mathrm{~min}$ of discovery of the fire and the building and its contents were consumed within $1 \mathrm{hr}$.

The fire was investigated by the Alaska State Police. The investigating officer reported that the fire started in the northeast corner of the building, where there was no power or heating, and spread rapidly throughout the building. He indicated that he had not been able to determine the actual cause of the fire, but it may have resulted from smoldering insulation or wood in the northeast corner. Several village youngsters had built a small bonfire near the northeast corner of the building several days preceding the fire, and it may have ignited the insulation and started it smoldering. 


\subsection{COMMUNITY REACTION}

There was no adverse reaction by community residents to the release of the tritium. They had been thoroughly briefed on safety and security needs for handling, using and storing the lights when the runway lighting system was installed, and they acted accordingly. They expressed appreciation of PNL's rapid response and action to establish the consequences of the release of radioactive tritium by the fire. They were very cooperative in following our instructions for restricting entry to the site and in assisting our investigation. Their cooperation is greatly appreciated by the authors. The residents expressed the desire that the RL lighting system continue to light the Melsing Creek runway and are hoping that the RL system will be transferred to the planned runway to be constructed south of the community in 1988.

Discussions with Gary Longly, Community Affairs, and Simon Mawson, Alaska Department of Environmental Quality, in Nome were also positive. Both voiced minimal concern over the release and supported use of the lights at runways in rural Alaska.

\subsection{NOTIFICATIONS}

The fire was reported to ADOT\&PF Research early in the day on September 9, 1987. A00T\&PF notified PNL staff late in the afternoon of September 9 , and PNL immediately notified DOE Richland Operations Office (DOE-RL) and DOEHQ of the event. ADOT\&PF handled immediate notification of Sidney Heidersdorf, Alaska Radiological Health, and other Alaska State organizations concerning the fire. G. A. Jensen (PNL) handled follow-up notification of ADOT\&PF and others concerning the results of the investigation and recovery actions. ORNL and DOE's Oak Ridge Operations Office were notified of the event on September 10,1987, by G. A. Jensen. 


\subsection{PLANNING, RECOVERY, SAMPLING, AND RESULTS}

In this section, the planning, information on handling and recovery of damaged panels, and the sampling procedures, data obtained, and analyses are presented.

\subsection{PLANNING}

Initial information was sketchy concerning the extent of damage to the RL light panels and the exact condition of the site after the fire. ADOT\&PF research personnel requested that an ADOT\&PF employee from Nome be sent to Council to make a preliminary assessment of the damage and report.

Plans for the recovery and investigation were based on the reported information that only the light tubes remained and that the aluminum boxes and polycarbonate covers had been destroyed. Additional information suggested that several tubes were green and possibly glowing, indicating that perhaps not all the tritium had escaped. Also there was some uncertainty as to exactly how many panels had been stored in the building. ADOT\&PF research personnel later reported that 12 panels had been destroyed, which was confirmed during PNL's investigation at the site.

The plan for the recovery and evaluation is found in Appendix A. Appropriate means for returning the damaged RL light tubes to Richland were developed through discussions with PNL shipping personnel prior to their leaving for Alaska and were reevaluated after examination of the fire site. Further discussions with PNL, Westinghouse Hanford shipping personnel, and other experts (by telephone) modified the original concept to that described in Appendix B. Tritium-monitoring equipment, sampling bottles, plastic bags for vegetation samples, surgeon's gloves, tritium smearing equipment and solutions, special clothing, and other items were assembled and prepared for shipment to Nome. Six Type 17H barrels, absorbent, calibration sources, and counting solutions were also assembled and shipped to Nome. The authors departed for Nome on September 14, 1987. 


\subsection{HANDLING AND RECOVERY OF LIGHT TUBES}

Delays in receiving the equipment and supplies required that the test team delay the recovery effort until September 17, 1987. However, the team visited the site on September 15, 1987, to obtain photographs, make their own assessment of the damage, finalize details for recovery of the remains of the panels, and identify locations for sampling vegetation and water.

\subsubsection{Approach to the Fire Site}

The site of the fire was approached very carefully since tritium contamination levels were not known. The area surrounding the building remains had been maintained undisturbed from the time of the fire until the recovery team arrived. The panels had been stored near the center of the building, and many of the RL tubes were in orderly rows similar to the unburned panels (Figures 7 and 8). Additional tubes lay scattered on the ground nearby (Figure 9). Most tubes were badly disfigured, indicating that temperatures during the fire had at least reached the softening point of glass; most

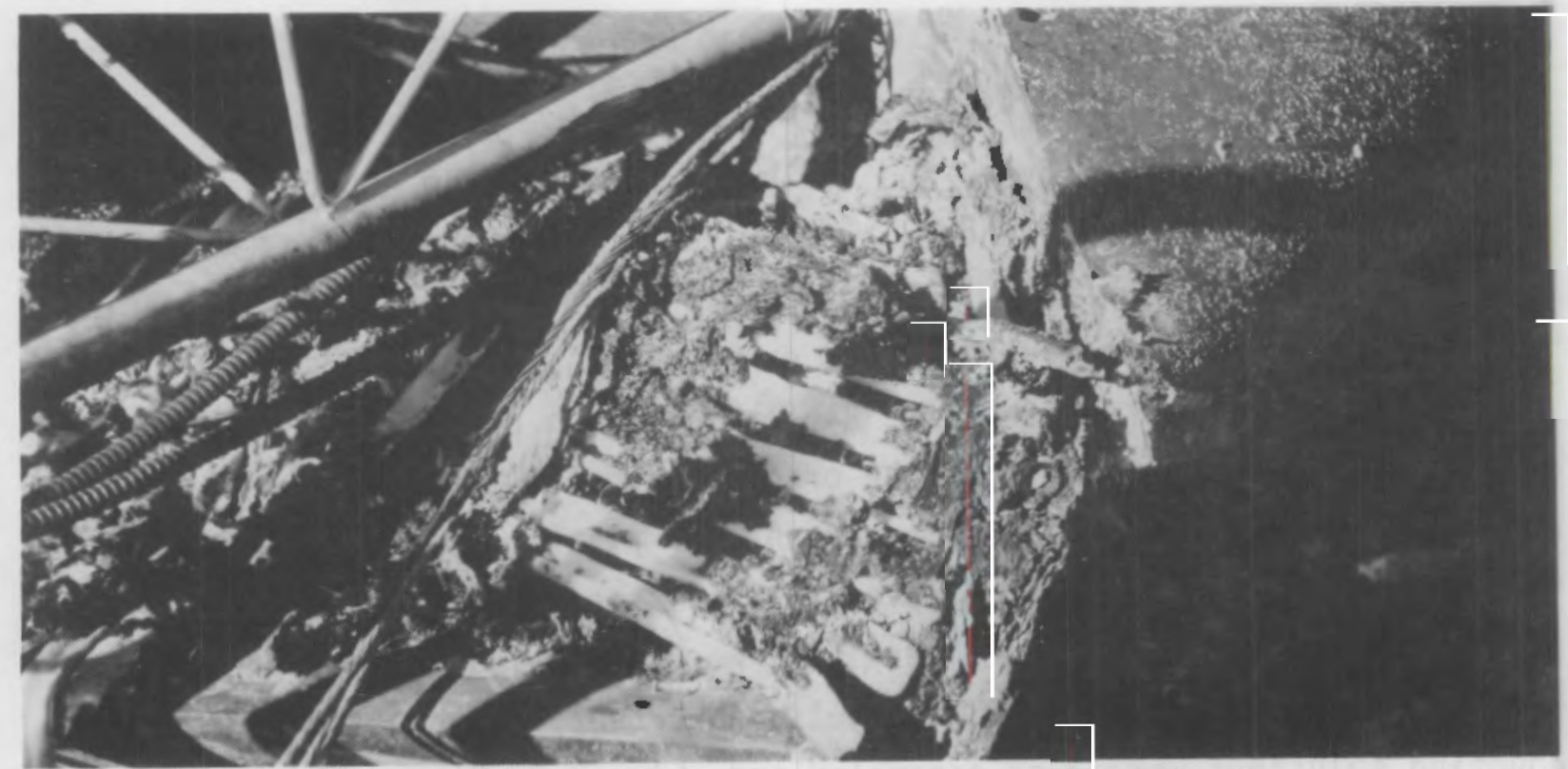

FIGURE 7. Fire-Damaged RL Light Panels 


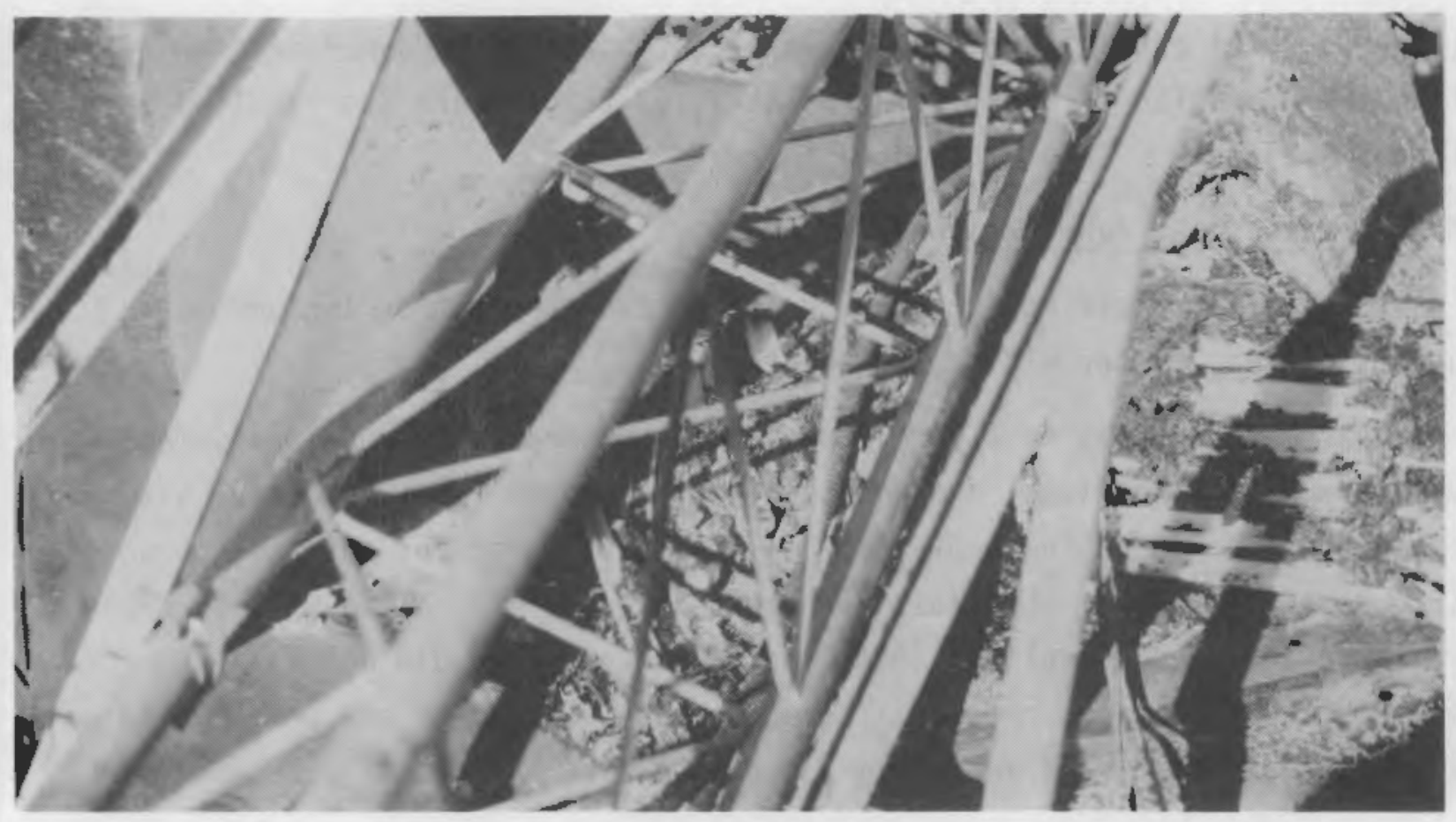

FIGURE 8. Fire-Damaged RL Light Panels



FIGURE 9. Fire-Damaged RL Light Panels 
(later careful examination revealed all) were damaged in a manner showing that the expansion of the tritium at elevated temperature had resulted in tritium release.

\subsubsection{Damaged RL Tube Recovery Procedure}

Protective clothing worn during the recovery operation included surgeon's gloves, rubber gloves, and boots.

Damaged RL tubes were recovered in order based on the obvious damage to the tube. Thus the least damaged tube was recovered first, smeared, visually examined, and placed in a polystyrene support prepared for shipping purposes (Figures 10 and 11). The glass strength was good, and, although many tubes showed evidence of "crazing" (many small cracks), they did not fall apart. The next 18 tubes were recovered based on observed damage and were placed in polystyrene support and sealed in a 5-gallon can. All other tubes and



FIGURE 10. Damaged RL Light Tubes in Polystyrene Packaging 


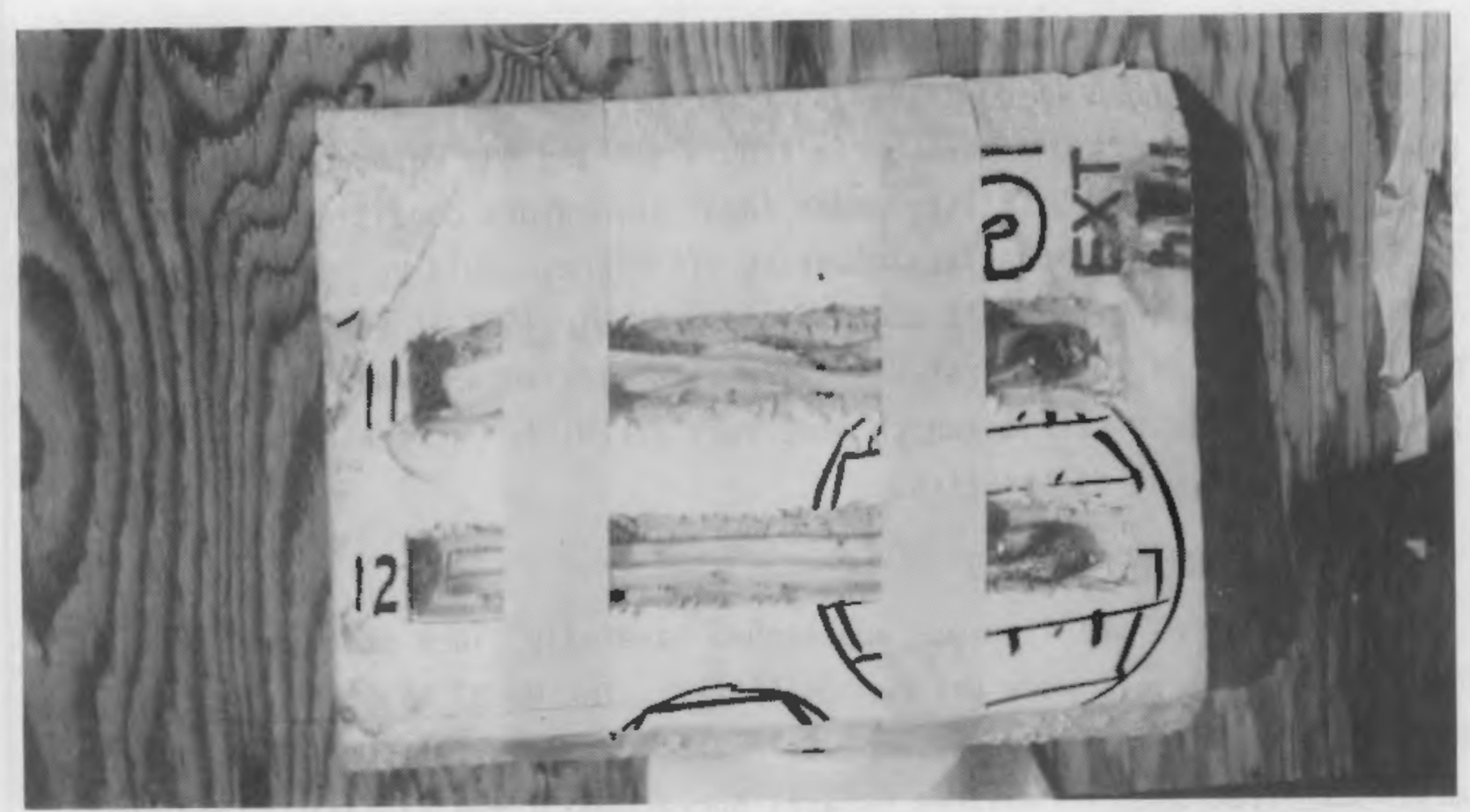

FIGURE 11. Damaged RL Light Tubes in Polystyrene Packaging

residual glass pieces were placed in absorbent in two additional 5-gallon cans and these were sealed. The 5-gallon cans were then sealed in the $17 \mathrm{H}$ drums with additional absorbent and prepared for shipment to PNL at Richland, Washington, for further evaluation or disposal.

\subsection{SAMPLING, ANALYSIS, AND RESULTS}

\subsubsection{Radiation Survey Instruments}

Portable instrumentation for real-time monitoring of tritium in the environment is very limited and relatively insensitive. Two instruments were used to monitor the scene of the fire for tritium contamination. The first was a Johnston Laboratories, Inc., Model 1055B Tritium Monitor. The instrument has dual ion chambers designed to compensate (correct) for gamma background radiation. It is battery-powered, has an internal pump, and can detect up to $50 \mu \mathrm{Ci} / \mathrm{m}^{3}$ of airborne contamination on the most sensitive range. The instrument also has a gamma dose rate mode that was used to check the local gamma background levels. 
The second instrument was a Berthold Model LB 1210B count rate meter with a Model LB 6355 windowless, gas-flow, proportional counter probe. The probe operates on P-10 counting gas (10\% argon and $90 \%$ methane) and is $28 \%$ efficient for counting tritium under ideal laboratory conditions. Under field counting conditions, the counting efficiency could be reduced to $10 \%$ or less. Thus the instrument's accuracy is probably $\pm 50 \%$ at best, and plus or minus a factor of 10 at worst. Despite this limited accuracy, the instrument provided immediate results which were very useful for screening smear samples taken at the scene of the fire.

\subsubsection{Radiation Monitoring}

The scene of the fire was approached carefully since potential tritium contamination levels were unknown initially. The Model 1055B Tritium Monitor was used as a "sniffer" to attempt to detect airborne tritium. The instrument was first used to monitor natural background garma radiation ( $10 \mu \mathrm{R} / \mathrm{hr}$ ) to confirm its operational status. No airborne tritium was detected around the perimeter of the fire debris. Next the sniffer was held directly above several of the damaged but undisturbed tritium light tubes. Again no airborne tritium was detected. The tritium monitor was then used as a continuous air monitor during the recovery operations.

The Berthold proportional counter was set up in a field counting station that was designed to control the spread of contamination and to prevent cross-contamination between smear samples. A bench was covered with plastic, and additional sheets of plastic were used to prevent contamination of the proportional counter probe assembly. In this configuration, the background count rate was 13 counts per second (cps) $\neq 2 \mathrm{cps}$. The performance of the instrument was checked by counting clean smears. Dry, clean smears did not affect the background count rate. Clean smears wet with ethylene glycol caused the background count rate to increase to about $250 \mathrm{cps}$. Clean smears wet with clean water caused the instrument to read off-scale high, i.e., greater than $3000 \mathrm{cps}$. It was decided to use dry smears even though the probability of transferring tritium contamination from a surface to the smear was reduced. 
A dry smear was taken on the side of a bookcase directly above several of the tritium light tubes. It read only $7 \mathrm{cps}$ above background, but this result could be suspect due to the dirt and soot on the smear. Next, the least damaged tritium light tube was picked up, and three dry smears were taken on its surfaces as noted in Table 1. A total of 72 tubes were recovered and smeared. A few additional small pieces of tubes were also recovered but not smeared.

In each case, most of the surface area of the tube (approximately $100 \mathrm{~cm}^{2}$ ) was smeared. Exceptions are explained in footnotes to the table. Results are presented in three columns. The first column gives the gross count rate as read on the instrument in cps. In the second column, background is subtracted, the count rate is converted to a disintegration rate assuming a nominal counting efficiency of $10 \%$, and the smear is assumed to have covered an area of $100 \mathrm{~cm}^{2}$. These results are presented for the first 19 tubes that were recovered from the fire debris.

At this point it was decided to suspend counting each smear with the proportional counter for the following reasons: Only one smear (Tube 13) had a significant result (i.e., greater than $3000 \mathrm{cps}$ ), and a resurvey of Tube 13 indicated the high count was suspect. The proportional counting operation was very time-consuming, and approaching darkness and cold weather suggested the recovery operation should be expedited. Therefore, smears from the remaining tubes were placed directly into vials of liquid scintillation solution for later analysis at PNL. Smears from the first 19 tubes were also placed in vials of liquid scintillation solution after being counted with the proportional counter.

The third column of Table 1 presents the results of liquid scintillation counting performed upon return to PNL on September 21 and 22, 1987. The net count rate was converted to a disintegration rate for each sample by an automatic process that uses an internal standard to correct for specific quenching effects. Tritium counting efficiencies ranged from 43 to $50 \%$ for this set of samples. Results in columns two and three are presented in disintegrations per minute $(\mathrm{dpm})$ per $100 \mathrm{~cm}^{2}$, permitting direct comparison for the first 19 tubes. 
IABLE 1. Tritiun Smear Results $($ a)

A. Initial Samples

$\frac{\text { Sample Description }}{\text { Nos }} \frac{\begin{array}{l}\text { Sample } \\ \text { No. }\end{array}}{d p m / 100 \mathrm{~cm}^{2} \quad \frac{1}{\text { Counter }}}$

Side of bookcase

- dry

Side of bookcase

- wet with ethylene

1

20

70

3100

glycol

Clean smear - wet

with ethylene glycol

side of bookcase

- wet with water

Clean smear - wet

with water

2

250

2400

78

Scintillation

Counter

3

250

2400

26

$4>3000>30,000$

1100

$5>3000>30,000$

14

B. Smears from Iritium Light Tubes

\begin{tabular}{|c|c|c|c|c|}
\hline \multirow[b]{2}{*}{$\begin{array}{l}\text { Tube } \\
\text { No. }\end{array}$} & \multirow[b]{2}{*}{$\begin{array}{c}\text { Sample } \\
\text { No. } \\
\end{array}$} & \multicolumn{2}{|c|}{$\begin{array}{c}\text { Proportional } \\
\text { Counter }\end{array}$} & \multirow{2}{*}{$\frac{\begin{array}{c}\text { Liquid } \\
\text { Scintillation } \\
\text { Counter }\end{array}}{\text { dpm/100 } \mathrm{cm}^{2}}$} \\
\hline & & $\cos$ & $\mathrm{dpm} / 100 \mathrm{~cm}^{2}$ & \\
\hline $\begin{array}{c}1 \\
1 \\
1 \\
2 \\
3 \\
4 \\
5 \\
6 \\
7 \\
8 \\
9 \\
10 \\
11 \\
12 \\
13 \\
14 \\
15 \\
16\end{array}$ & $\begin{array}{l}6(\mathrm{~b}) \\
7(\mathrm{c}) \\
8(\mathrm{~d}) \\
9 \\
10 \\
11 \\
12 \\
13 \\
14(\mathrm{c}) \\
15 \\
16 \\
17 \\
18 \\
19 \\
20 \\
21 \\
22 \\
23\end{array}$ & $\begin{array}{r}22 \\
18 \\
70 \\
18 \\
40 \\
200 \\
42 \\
115 \\
250 \\
23 \\
20 \\
50 \\
21 \\
48 \\
>3000 \\
90 \\
55 \\
30\end{array}$ & $\begin{array}{r}90 \\
50 \\
570 \\
50 \\
270 \\
1900 \\
290 \\
1000 \\
2400 \\
100 \\
70 \\
370 \\
80 \\
350 \\
>30,000 \\
770 \\
420 \\
170\end{array}$ & $\begin{array}{r}48,000 \\
13,000 \\
31,000 \\
10,000 \\
26,000 \\
77,000 \\
26,000 \\
52,000 \\
100,000 \\
8,100 \\
13,000 \\
15,000 \\
6,100 \\
27,000 \\
190,000 \\
120,000 \\
19,000 \\
5,900\end{array}$ \\
\hline
\end{tabular}


B. Smears from Tritium Light Tubes - Continued

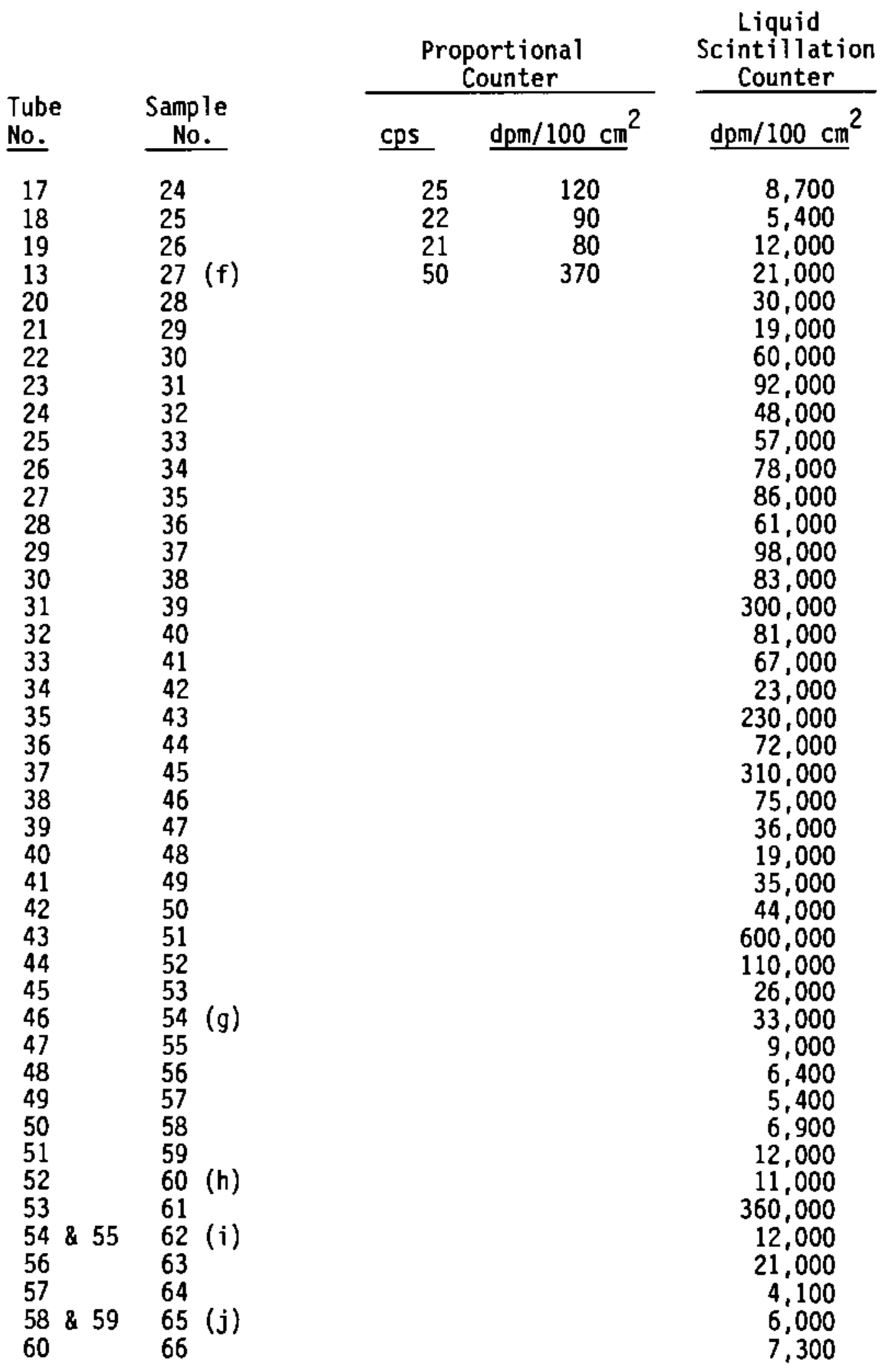


B. Smears from Tritium Light Tubes - Continued

\begin{tabular}{|c|c|c|c|}
\hline \multirow[b]{2}{*}{$\begin{array}{l}\text { Tube } \\
\text { No. } \\
\end{array}$} & \multirow[b]{2}{*}{$\begin{array}{l}\text { Sample } \\
\text { No. }\end{array}$} & $\begin{array}{c}\text { Proportional } \\
\text { Counter }\end{array}$ & $\begin{array}{c}\text { Liquid } \\
\text { Scintillation } \\
\text { Counter } \\
\end{array}$ \\
\hline & & cps $\quad \mathrm{dpm} / 100 \mathrm{~cm}^{2}$ & $\mathrm{dpm} / 100 \mathrm{~cm}^{2}$ \\
\hline $\begin{array}{l}61 \\
62 \\
63 \\
64 \\
65 \\
66 \\
67 \\
68 \\
69 \\
70 \\
71 \\
72\end{array}$ & $\begin{array}{l}67 \\
68 \\
69 \\
70 \\
71 \\
72 \\
73 \\
74 \\
75 \\
76 \\
77 \\
78\end{array}$ & $\begin{array}{r}8,000 \\
24,000 \\
34,000 \\
17,000 \\
13,000 \\
24,000\end{array}$ & $\begin{array}{l}29,000 \\
24,000 \\
50,000 \\
15,000 \\
21,000 \\
32,000\end{array}$ \\
\hline
\end{tabular}

\footnotetext{
(a) Results are rounded to two significant figures

(b) Smear taken from the middle of Tube 1

(c) Smear taken from the damaged end of Tube 1

(d) Smear repeated on the niddle of Tube 1

(e) Smear taken from middle and damaged end of Tube 7

(f) Smear repeated on Tube 13

(g) Tube 46 was in three pieces

(h) Tube 52 was in two pieces

(i) Tubes 54 and 55 were fused together and were treated as a single tube

(j) Tubes 58 and 59 were fused together and were treated as a single tube.
}

A comparison of the second and third columns of results for the first 19 tubes indicates that the liquid scintillation results are consistently higher than the proportional counter results. The ratios of results range from 6 for Tube 13 (a suspect result) to 533 for Tube 1. Most of the ratios range between 40 and 200 , and these results are considered roughly comparable. In any case, the more significant conclusion is that residual tritium contamination on the tubes ranged from near background to sub-microcurie levels, and these levels represent a negligible risk. 


\subsubsection{Bioassay Samples}

Urine bioassay samples were collected from residents of Council, employees of the ADOT\&PF, and PNL staff as a means of assessing the potential for internal tritium contamination. If exposure to airborne tritium had occurred during the fire or the recovery operations, or if people were exposed to contaminated water or vegetation, sensitive bioassay analyses would have detected body water concentrations of tritium in excess of $10 \mathrm{dpm} / \mathrm{mL}$ (0.0005 microcuries/liter). A single exposure of tritium that results in internal contamination at the detection limit equates to an integrated dose of about $0.02 \mathrm{millirems}$ (or about $0.01 \%$ of the average exposure received annually from natural background radiation).

Urine samples were collected from six residents of Council who were present at the scene during the fire on September 6 . Each of these people had stood within $100 \mathrm{~m}$ of the fire for about 1 hour. These same people continued to live normally within the community for the following 10 to 14 days, at which time the samples were collected. However, none of these people disturbed the fire debris or directly handled the tritium light tubes. Results of these bioassays are presented in Table 2.

Urine samples were collected also from employees of the ADOT\&PF who visited the scene of the fire between September 8 and 15 and assisted with recovery operations on September 17 . These people worked in the fire debris but did not directly handle the tubes. Samples were collected also from PNL staff members G. A. Jensen and J. B. Martin, who recovered the remains of the tubes from the fire debris. Results of these bioassays are also presented in Table 2.

Table 2 shows that none of the Council residents or employees of ADOT\&PF or PNL received a measurable exposure to tritium as a result of the fire. However, G. A. Jensen apparently received a prior low-level exposure unrelated to the recovery operation. On September 12, 1987, the result of his bioassay was well above the $10 \mathrm{dpm} / \mathrm{mL}$ detection limit, indicating that tritium exposure had been received prior to his departure for Alaska. The September 17, 1987, sample indicated excellent agreement with the 10-day tritium biological half life, implying that no tritium exposure was incurred 


\section{IABLE 2. Tritium Bioassay Results}

Individual

Council Residents

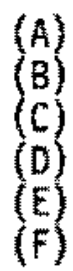

ADOT\&PF Enployees

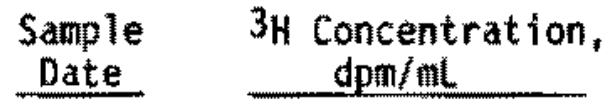

$9 / 18 / 87$

$9 / 18 / 87$

$9 / 18 / 87$

$9 / 18 / 87$

$9 / 18 / 87$

$9 / 20 / 87$
No
No
ND
ND
No
No

เก

6.3

ND

PAl. Emp Toyees

3. B. Martin

$9 / 15 / 87$

$9 / 15 / 87$

$9 / 18 / 87$

J. B. Martin

$9 / 12 / 87$

11.6

$9 / 17 / 87$

6.8

J. B. Martín

$9 / 23 / 87$

$9 / 12 / 87$

$9 / 17 / 87$

G. A. Jensen

$9 / 23 / 87$

6.0

212.0

158.0

267.0

$\begin{aligned} \text { NO * } & \text { None detectable. Result was less than the associated } \\ & \text { two-signa uncertainty. }\end{aligned}$

between September 12 and 17 during 6. A. Jensen's visit to the site and his participation in the recovery activities. The september 17 sample was obtained the night after the completion of the recovery operation and was the last day that exposure was possible during 6 . A. Jensen's stay in Alaska. The Septenber 23, 1987, sample was obtained several days after G. A. Jensen's return to Richland, Washington, and it indicated additional tritiun exposure after his return to Richland, Washington. The September 23 sample was comparable to the September 12 sample. The inplication of the september 23 sample is that $G$. A. Jensen is receiving a low-level tritium intake associated with his nomal work activity. The intake appears to approximate a chronic low-level exposure condition, is estimated at about 8 mrem/year, and 
is less than $1 \%$ of the applicable DOE Radiation Protection Standard. G. A. Jensen has been placed on a more frequent sampling program in an effort to determine the source of the exposure.

\subsubsection{Environmental Samples}

Vegetation and water samples were collected from the locations shown in Figure 12 to assess potential environmental contamination from the tritium release. Grass, moss, leaves, weeds, and pine needles were collected and placed in plastic bags, which were then sealed and carefully labeled. As gardening is not attempted in the area, no food crop vegetation material was collected. The map in Figure 12 represents a square 2 miles on a side covering the area surrounding Council. Samples of standing water were collected from several locations, and running water was obtained from Melsing Creek and the Niukluk River. Additional water samples were obtained from Bear Creek ( 6 miles distant) and from streams near Nome (50 miles distant) to establish the background tritium levels for the region. Vegetation samples were also obtained near these locations. The environmental samples were analyzed by U.S. Testing $\mathrm{C}_{0}$. Richland, Washington, using standard methods established under contract with PNL. The results of these analyses are presented in Table 3 .

The results reported in Table 3 indicate that the tritium found in samples taken near Council was not significantly different than samples taken several miles from Council and near Nome. All of these samples reflect the normal variations of natural background levels of tritium in the environment. 


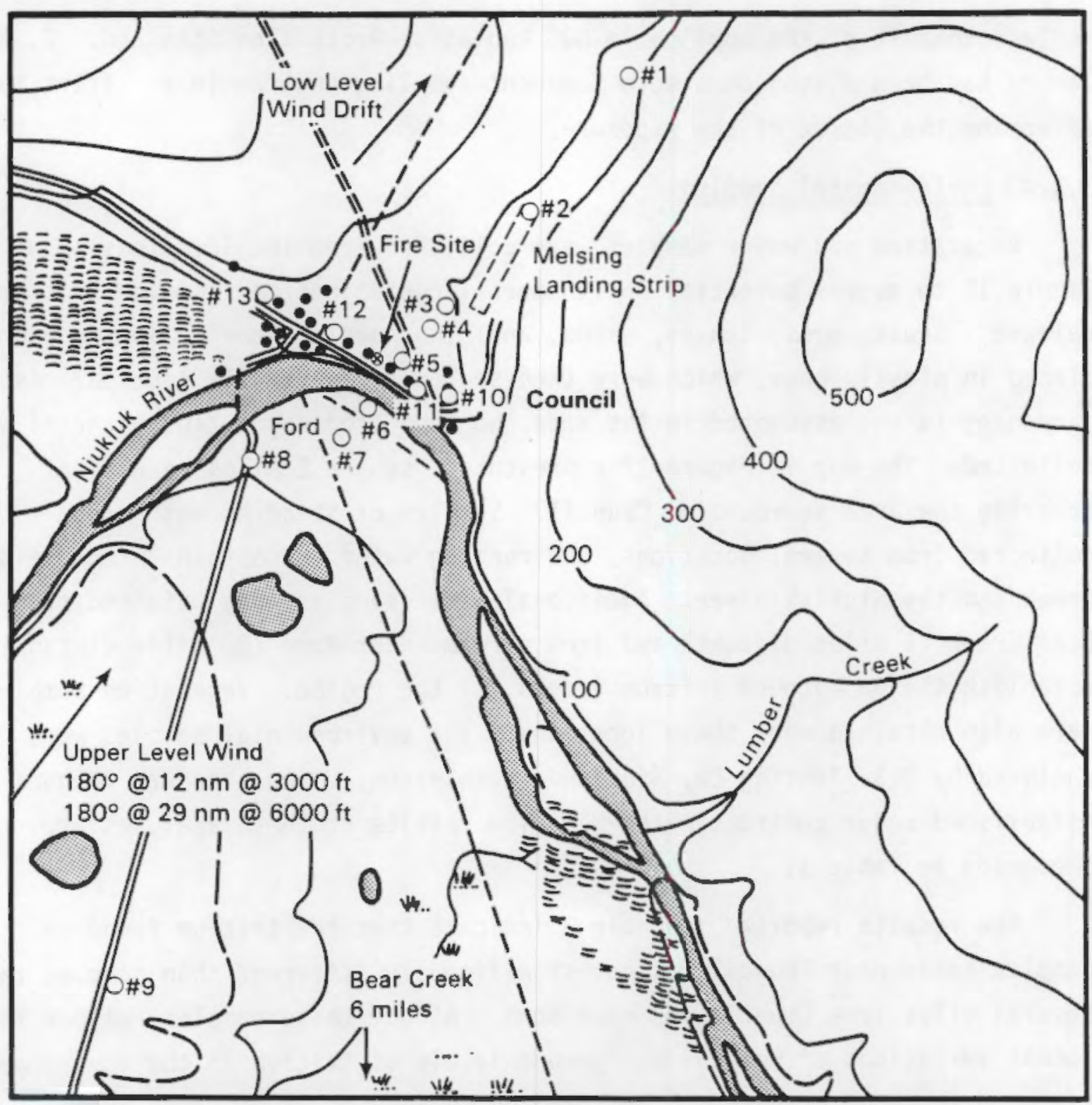

FIGURE 12. Vegetation Sampling Locations Near Council 
TABLE 3. Environmental Sample Results

\title{
VEGETATION SAMPLE IDENTIFICATION
}

\author{
${ }^{3}$ H Concentration \\ $(m i C i / L)$
}

\section{Council Area}

1 Jeep Trail 0.3 Mi N. of Runway

0.12

N. End of Runway

0.05

Wind Tee

0.04

Jeep Trail $0.25 \mathrm{mi}$ N. Fire Site

0.03

Jeep Trall 0.25 mi N. Fire Site

0.04

0.11

Bluff Across Road S. Fire Site

0.03

7 Across River S. Fire Site

0.05

8 Across River $0.15 \mathrm{mi}$ S.Edge of Road

0.03

10 Next to First Bldg. E. of Fire Site

0.09

11 East Edge of Council

120.15 mi West of Fire Site

0.06

13 West Edge of Council

0.05

0.11

Areas Distant from Council

Bear Creek - 1

Bear Creek - 2

0.04

Areas Near Nome

Teller Highway - 9 Miles

ND *

Taylor Highway - 13 Miles

ND

Nome - 121 Kings Way (Soil)

ND

\section{WATER SAMPLE IDENTIFICATION}

Sources Near Council

10.3 mi N. of Runway, Melsing Creek NO

10.3 mi N. of Runway, Pond

ND

2 Puddle N. End of Runway

0.001

9 Across River $0.5 \mathrm{mi} \mathrm{S}$. Edge of Rd. $\quad 0.002$

Niukluk River at Ford

ND

Sources Distant from Council

Bear Creek - 6 miles

ND

Sources Near None

Teller Highway - 9 Miles Fron None

Taylor Highway - 13 Miles From Home

ND

ND

ND * None detectable. Result was less than the associated two-signa uncertainty. 







\subsection{CONCLUSIONS}

All of the tritium contained in the 12 paneis destroyed in the fire (3000 Ci) was released to the atmosphere. The fire was very hot and carried the tritium several hundred feet upward, where it dispersed rapldly and was carried away by upper-level air currents. No tritium exposure was found in individuals who watched the fire or moved equipment away from it or recovered damaged RL light tubes. Environmental vegetation and water samples obtained in Council, the surrounding area, and distant locations showed nomal variations for natural background Tevels of tritium in the environnent. 


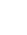

+ 
APPENDIX A

RECOVERY PLAN 
EVALUATION PLAN FOR COUNCIL, ALASKA FIRE INVOLVING RAOIOLUMINESCENT LIGHTS

September 14,1987

\section{BACKGROUND}

For several years the State of Alaska and the DOE have co-funded an ongoing study of OOE-fabricated radioluminescent lights for remote Alaska airport runways. The radioactive material in the lights is tritium gas. Three runways have been equipped with radioluminescent lights. They are lacated at Central (100 mi ENE of Fairbanks). Tununak (50 mi from Bethel on the Bering Sea coast) and Council (50 mi ENE of Nome). The Central runway tritium inventory is about $46,000 \mathrm{Ci}$. The Tununak and Council runway tritium inventories are each about $38,000 \mathrm{Ci}$. The population of Council is from 15 to 20 people.

PNL provides technical support to the program, reporting directly to John Mathur, Program Manager, OOE-HQ, DP 123.

\section{THE SITUATION}

Late Tuesday, September 8, PNL was informed that there had been a storage building fire at Council, and that some of the iights in storage may have been involved. Late Wednesday we were informed that a State of Ailaska Department of Transportation and Public Facilities (DOT\&PF) staff member had visited the site and confirmed that lights were in the builoing that burned and the fixtures holding the tritium loaded glass tubes had mostly burned away. He aiso reported that some of the tubes were still emitting radioluminescent light. Alaska estimates that from 6 to 8 iight panels were invoived in the fire. Each panel contains 7 light tubes and about $350 \mathrm{C}$ of tritium.

Late Thursday, John Mathur requested that PNL take the lead in evaluating the aftermath of the fire.

\section{EVALUATION GOALS}

- Complete a technical evaluation of the aftermath of the Council Airport fire in orjer to identify strengths and weaknesses of the gas-tube lign: design in a fire environment.

- Evaluate the impact, if any, on the local residents and immediate environment.

\section{EVALUATION OBJECTIVES}

- Obtajn and evaluate urine specimens from Council residents near the fire.

- Obtain and evaluate foliage/terrain/water samples within 100 meter radius. 
- Determine the number of light panels that were in storage, and that were involved in the fire.

- Evaluate the site for technical information on integrity of lights in a fire situation.

- Package remains of lights and send to Hanford for further evaluation.

- Prepare a letter report on the evaluation results.

\section{ACTIONS TAKEN}

- The Alaska State Police initially investigated the scene of the fire.

- Initial information on the fire came from Lee Leonard, State of Alaska DOT\&PF. The following people have been informed:

- State of Alaska - Sid Heidersdorf, State Health Physicist.

- DOE-HQ - John Mathur, Dick Chitwood.

- DOE-RL - Gary Rosenwald, Cesar Collantes, John Hunter, Eric Erichsen, Dave Evans and Tom Bauman.

- PNL - George Jensen, Jim Jarrett, Jack MCE]roy, Joe Berry, Jerry Martin, Dave Broussard and Jerry Holloway.

- DOE-OR - D. R. BrOWn

- ORNL - Kari Haff.

- A State of Alaska - DOT\&PF staff member located in Nome travelect to the site and observed that the fire burned the lights extensively, yet many of the tubes were producing light, indicating that these tubes still had their integrity.

c Mr. John Mathur, DOE-OP, Manager of the DP Radioiuminescent Lights work has requested that PNL develop and implement an evaluation plan for the Council Alaska fire involving radioluminescent lights. PNL has assigned Dr. George Jensen to lead the evaluation operation.

- The evaluation plan was sent out far review Friday, September 11. This September 14 plan incorporates conments from DOE-HQ, DOE-RL, the State of Alaska and PNL.

\section{PLANNED ACTIONS}

- Ship 6 30-galion drums (DOT approved shipping containers) to Nome Friday (arrival expected by Monday). Drums will be used to pack light remains for shipment to Hanford. If all are not needed, one extra will be stored at Council, other extras will be sent to Central and Tununak (the two other experimental runways)."- 
- George Jensen and Jerry Martin, a PNL health physicist, travel to Nome Monday.

- PNL staff and Alaska DOT staff member travel by air to Council Tuesday, start bioassay work and take foliage and ground samples. Start evaluation of fire scene. Return to Nome Tuesday afternoon.

- Evaluation team return to Council Wednesday and Thursday (if necessary) to complete evaluation of fire scene and package material for shipment to Hanford for further evaluation as deemed necessary.

- Protective clothing will be worn, protectivi glcves will be changed frequently depending on activities.

- Jensen to inform John Mathur, Lee Leonard and PNL (Jim Jarrett) of progress. PNL to inform Gary Rosenwald, DOE-RL.

- Media questions will be referred to Lee Leonard. Should Nome media questions arise while the PNL team is in Nome, they will be addressed by Jensen. 


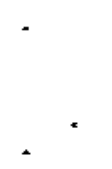


APPENDIX B

METHOD OF PACKAGING DAMAGED RL LIGHT TUBES FOR SHIPMENT 
APPENDIX 8

METHOD OF PACKAGING DAMAGED RE LJGHT TUBES FOR SHIPMENT

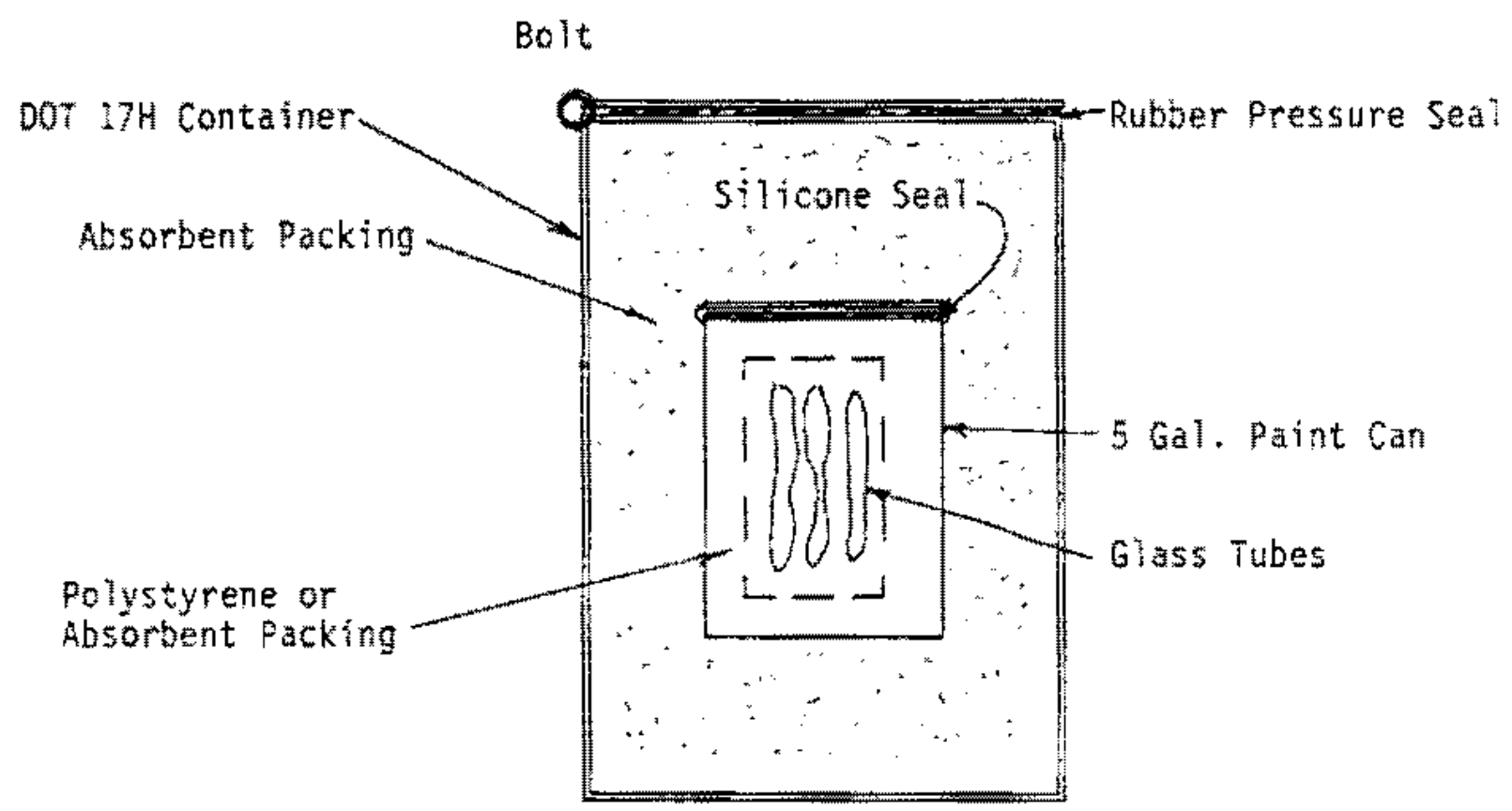









\section{DISTRIBUTION}

No. of

Copies

OFFSITE

2 M. D. Travis

State of Alaska DOT\&PF

2361 Peger Road

Fairbanks, AK 99708

L. E. Leonard

Advanced Radiation Technology Progran

U. 5. DOE

NE-24

Washington, DC 20545

R. B. Chitwood

Advanced Radiation Technology Progran

U.S. DOE

$N E-24$

Washington, oC 20545

5. D. Heldersdorf

Radiological Health

Department of Health $\mathrm{a}$ Social Services

Division of Public Health

Pouch $\mathrm{H}-\mathrm{DGF}$

Juneau, AK 99811

10 DoE office of Scientific and Technical Information

K. W. haff

Oak Ridge Hational Laboratory

P.O. Box $X$

Dak Ridge, TN 37830

J. A. Tonpkins

Oak Ridge National Laboratory P.O. Box $x$

Oak Ridge, TN 37830
No, of

Copies

ONSITE

3 DOE Richland Operations Center

R. B. Goranson

D. L. Sours

J. J. Sutey

41 Pacific Northwest Laboratory

H. W. Ballard

J. H. Jarrett

G. A. Jensen (30)

3. L. MCElroy

G. L. Tingey

Publishing Coordination (2)

Technical Information (5) 


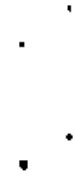

